\title{
Kinetic study of the gas-phase reactions of hydroxyl radicals and chlorine atoms with cis-3-hexenylformate
}

\author{
D. Rodríguez $\cdot$ A. Rodríguez $\cdot$ I. Bravo $~$ \\ A. Garzón · A. Aranda · Y. Diaz-de-Mera • \\ A. Notario
}

Received: 24 September 2013/Revised: 18 August 2014/ Accepted: 11 October 2014/Published online: 25 November 2014

(C) Islamic Azad University (IAU) 2014

\begin{abstract}
Recently, it has been demonstrated that grass and cut grass are important sources of C6 esters' emissions into the atmosphere. The esters emitted as part of the wound defense mechanisms are responsible for the smell of freshly cut grass and are also highly photochemically reactive. Thus, these grass emissions should be included in models of urban photochemical pollution so that accurate smog predictions can be obtained. In this work, we have carried out a kinetic study of the gas-phase reactions of chlorine atom and hydroxyl radical with cis-3-hexenylformate $\left(\mathrm{HCO}_{2} \mathrm{CH}_{2} \mathrm{CH}_{2} \mathrm{CH}=\mathrm{CHC}_{2} \mathrm{H}_{5}\right)$ for the first time. This was performed in a Teflon static reactor at room temperature and atmospheric pressure of nitrogen or air using gas chromatography with flame ionization detection. Kinetic rate coefficients obtained for $c i s$-3-hexenylformate were (in units of $\mathrm{cm}^{3}$ molecule $\left.\mathrm{s}^{-1}\right)(2.45 \pm 0.30) \times 10^{-10}$ and $(4.61 \pm 0.71) \times 10^{-11}$ for chlorine and hydroxyl radical reactions, respectively. The reaction between the ester and
\end{abstract}

Electronic supplementary material The online version of this article (doi:10.1007/s13762-014-0686-9) contains supplementary material, which is available to authorized users.

D. Rodríguez $(\square) \cdot$ A. Rodríguez

Faculty of Environmental Sciences and Biochemistry, University of Castilla La Mancha, Avenida Carlos III, s/n, 45071 Toledo, Spain

e-mail: diana.rodriguez@uclm.es

I. Bravo · A. Garzón

Faculty of Pharmacy, Physical Chemistry Department, University of Castilla La Mancha, Edificio Polivalente, s/n, 02071 Albacete, Spain

A. Aranda $\cdot$ Y. Diaz-de-Mera $\cdot$ A. Notario Faculty of Chemical Sciences, University of Castilla La Mancha, Avenida Camilo José Cela, n ${ }^{\circ}$, 13071 Ciudad Real, Spain chlorine atoms is very fast, approaching the collisioncontrolled regime; nevertheless, the rate constant for the reaction with hydroxyl radical is lower. In addition, the rate coefficients for the reactions of cis-3-hexenylformate with different atmospheric reactive species were estimated through a Quantitative Structure-Activity Relationship model in which High Occupied Molecular Orbital energy of the formate is used as a theoretical molecular descriptor. Tropospheric lifetimes, based on the homogeneous sinks of the cis-3-hexenylformate, are estimated from the kinetic data obtained in the present work. The relatively short atmospheric lifetimes of the ester indicate that the compound will be oxidized near its anthropogenic origin source.

Keywords Atmospheric lifetimes - Chlorine atoms - Cis3-hexenylformate - Hydroxyl radicals - Rate coefficients . Smog chamber

\section{Introduction}

The importance of the atmospheric chemistry of oxygenated volatile organic compounds (OVOCs) has lately increased due to their role in indoor pollution and secondary organic aerosol (SOA) formation, along with the potential toxicity of some of them and/or their degradation products (Kanakidou et al. 2005; Mellouki et al. 2003).

C2-C7 esters are an important class of OVOCs which are extensively used as solvents (Grosjean and Grosjean 1999) and flavor scents in certain household goods (Pimentel et al. 2010). The esters are also indirectly emitted as primary products of the atmospheric oxidation of ethers and directly emitted into the atmosphere from 
vegetation (Helmig et al. 1999). Freshly cut grass is found to emit a complex mixture of $\mathrm{C} 6$ compounds (GLVs: Green Leaf Volatiles); C6-hexenyl compounds constitute $69 \%$ of the volatile emissions of the cut grass (characterized by a "freshly mowed lawn" smell). The most abundant species, which made up about $40 \%$ of the total, was cis-3-hexenyl acetate $\left(\mathrm{CH}_{3} \mathrm{OC}\right.$ $\mathrm{OCH}_{2} \mathrm{CH}_{2} \mathrm{CH}=\mathrm{CHC}_{2} \mathrm{H}_{5}$ ) (Kirstine et al. 1998). Studies such as Bicchi et al. 1989; Arey et al. 1991; Winer et al. 1992; König et al. 1995 show that one of the major ester emitted from vegetation is cis-3-hexenyl acetate. Together with cis-3-hexenyl acetate, several additional C6 esters such as cis-3-hexenylformate, trans-3-hexenyl formate, trans-3-hexenylacetate, cis-3-hexenyl n-butyrate, cis-3-hexenyl iso-valerate and one hexenyl hexanoate isomer were identified (Helmig et al. 1999).

Tropospheric degradation of esters occurs via reaction with hydroxyl radicals $(\mathrm{OH})$ during the daytime and with nitrate radicals $\left(\mathrm{NO}_{3}\right)$ at nighttime and ozone $\left(\mathrm{O}_{3}\right)$ during both day and night (Atkinson and Arey 2003; Martin et al. 2010). The main source of $\mathrm{OH}$ radicals in the atmosphere is generally assumed to be the photolysis of $\mathrm{O}_{3}$ that generates $\mathrm{O}\left({ }^{1} \mathrm{D}\right)$ atoms which are able to be quenched to ground-state oxygen atoms, $\mathrm{O}\left({ }^{3} \mathrm{P}\right)$, or react with water vapor to form $\mathrm{OH}$ radicals (Finlayson-Pitts and Pitts 2000). It is also well known that the ozonolysis of alkenes and the photolysis of nitrous acid (HONO) can be important sources of $\mathrm{OH}$ radicals, particularly in urban areas (Paulson and Orlando 1996); (Donahue et al. 1998) and (Paulson et al. 1999).

Until recently, the initiated chlorine atom $(\mathrm{Cl})$ oxidation of non-methane volatile organic compounds (NMVOCs) was generally only considered to be significant in coastal and marine air environments and in the Arctic troposphere during springtime (Arsene et al. 2007). It is because of the belief that the photolysis of chlorine containing compounds, generated in the heterogeneous reactions of sea-salt aerosols, was the main source of $\mathrm{Cl}$ atoms (Osthoff et al. 2008 and George et al. 2010). However, a recent field study shows the presence of nitryl chloride $\left(\mathrm{ClNO}_{2}\right)$, a gaseous photolytic $\mathrm{Cl}$ atom precursor, in continental regions far away from coastal and marine areas (Thornton et al. 2010; Phillips et al. 2012). These observations suggest that chlorine chemistry may possibly be ubiquitous in the atmosphere and play a significantly more important role than previously thought in the oxidizing capacity of the troposphere, particularly in the early morning. In urban environments, additional sources of $\mathrm{Cl}$ atoms due to industrial activities can exist; for example, in the vicinity of brick factories (e.g., heating of ceramic raw materials), concentrations of $\mathrm{Cl}$ atoms higher than the concentrations observed in marine coasts have been reported (Galáan et al. 2002).

The rate coefficients of unsaturated esters with $\mathrm{Cl}$ atoms are over one order of magnitude larger than the corresponding $\mathrm{OH}$ reaction (when available in the literature) (Martín et al. 2010). Thus, although the average tropospheric concentration of $\mathrm{Cl}$ atoms is much lower than that of $\mathrm{OH}$ radicals, the two reactions can compete in areas where the chlorine atom concentration is high enough.

In this work, we carried out a kinetic study of the gasphase reactions of $\mathrm{Cl}$ atom and $\mathrm{OH}$ radical with cis-3hexenylformate in a Teflon static reactor at room temperature and atmospheric pressure with gas chromatography with flame ionization detection (GC-FID). Rate coefficients of the considered reactions have not been previously determined. In addition, the perturbation frontier molecular orbital (PFMO) Theory (Fleming 2009) has been employed to theoretically estimate the value of the rate coefficients of the reactions of cis-3hexenylformate with different atmospheric radicals. A good understanding of the atmospheric oxidation processes of this unsaturated ester is needed to determine lifetime of this compound in the atmosphere and to assess the impact of these reactions on the formation of photo-oxidants and, therefore, on health and environment. This research has been carried out in the Department of Physical Chemistry, Faculty of Environment Science and Biochemistry, University of Castilla-La Mancha (Spain), from October 2011 to May 2012.

\section{Materials and methods}

A relative kinetic technique was used to determine the rate coefficients of the reactions of cis-3-hexenylformate with $\mathrm{OH}$ and $\mathrm{Cl}$ radicals. A detailed description of this technique and the appropriate mathematical kinetic analysis were previously reported at length by our laboratory (Rodríguez et al. 2012a, b). All the relative-rate experiments were carried out in a $400 \mathrm{~L}$ Teflon bag housed in an isothermal cabinet with six fluorescent lamps (Philips TUV G13. $36 \mathrm{~W}, \lambda_{\max }=254 \mathrm{~nm}$ ) mounted on the walls. In the smog chamber experiments, unwanted loss of reactants and products via photolysis, dark chemistry and heterogeneous reactions has to be considered. The photolysis at $254 \mathrm{~nm}$ of trichloroacetyl chloride $\left(\mathrm{CCl}_{3} \mathrm{COCl}\right)$ or of $\mathrm{H}_{2} \mathrm{O}_{2}$ was used to generate atomic chlorine and $\mathrm{OH}$ radicals, respectively. In this sense, $\mathrm{Cl}_{2}$ was not used as source of $\mathrm{Cl}$ atoms since $\mathrm{Cl}_{2}$ reacts with cis-3-hexenylformate in the dark. For each experiment, the total photolysis times were within 50-120 min. 
Reagents were obtained from commercial sources at the following purities: cis3-hexenylformate ( $\geq 94 \%$, Aldrich), trichloroacetyl chloride (99\%, Aldrich), hydrogen peroxide $(>60 \%$, Fisher Chemical), cyclohexane (99.9\%, Aldrich), octane ( $>99 \%$, Acros Organics), propene (>99\%, Aldrich) and 1-butene ( $\geq 99 \%$, Aldrich). Synthetic air (99.999 \%, Air Liquide) and $\mathrm{N}_{2}$ (99.999\%, Air Liquide) were employed as bath gases for the experiments, and $\mathrm{He}$ (99.998\%, Air Liquide) was used as GC carrier gas. Liquid samples were degassed several times by trapto-trap distillation before use. Concentration ranges of reference compounds, ester, $\mathrm{OH}$ and $\mathrm{Cl}$ precursor, are given in Table 1.

Decays of the ester and the reference hydrocarbon (reference) due to the reaction with the oxidant $\mathrm{Cl}$ or $\mathrm{OH}$ can be described by the following reactions:

ester $+\mathrm{Cl}($ or $\mathrm{OH}) \rightarrow$ Products $k_{\text {ester }}$

reference $+\mathrm{Cl}($ or $\mathrm{OH}) \rightarrow$ Products $k_{\text {ref }}$

where $k_{\text {ester }}$ and $k_{\text {ref }}$ are the rate coefficients for reactions of the oxidant with the cis-3-hexenylformate and the reference hydrocarbon, respectively. Considering that the ester and reference hydrocarbon were lost only by reactions 1 and 2, it can be shown that:

$\ln \left(\frac{[\text { ester }]_{0}}{[[\text { ester }]]_{t}}\right)=\frac{k_{[\text {ester }]}}{k_{\text {ref }}} \ln \left(\frac{[\text { reference }]_{0}}{[\text { reference }]_{t}}\right)$

where $[\text { ester }]_{0},[\text { reference }]_{0}$, [ester $]_{t}$ and $[\text { reference }]_{t}$ are the concentrations of the cis-3-hexenylformate and the reference hydrocarbon at times $t=0$ and $t$, respectively. Thus, a plot of $\left\{\ln [\text { ester }]_{0} /[\text { ester }]_{t}\right\}$ versus $\left\{\ln [\text { reference }]_{0} /[\right.$ reference $\left.]_{t}\right\}$ should be a straight line passing through the origin and whose slope yields the ratio of rate coefficients. Provided that $k_{\text {ref }}$ is known, the rate coefficient of the reaction $1, k_{\text {ester }}$, can then be determined by multiplying the slope by $k_{\text {ref. }}$.

Equation 3 relies on the assumption that cis-3-hexenylformate and the reference compound were removed solely by reaction with the oxidant $(\mathrm{Cl}$ or $\mathrm{OH})$. For each mixture of the organics compounds, a number the injections, usually 10 , of the unreacted mixture were carried out to obtain an estimate of the precision associated with the measurements in order to carry out the error analysis. The standard deviations $(2 \sigma)$ of these replicate injections were typically $2 \%$ for the ester and 1-2\% for the reference compounds. These measurements also included the losses with the walls of the reaction bag, and this set of experiments was performed three to six times on different dates, changing the reactants' concentrations. The reproducibility of the results shows that the wall losses of the reactants were not significant.
The decay of the ester and reference compound concentrations was followed using gas chromatography with flame ionization detection, GC-FID (Shimadzu 2010). Gas sample from the bag was injected using a port gas sampling valve (Valco Instruments Co. Inc) into a split/ splitless injector. The GC was equipped with a capillary column (size: $30 \mathrm{~m} \times 0.32 \mathrm{~mm} \times 1 \mu \mathrm{m}$. Meta.X5 Teknokroma) maintained isothermal at $100{ }^{\circ} \mathrm{C}$, for the reaction with $\mathrm{Cl}$ atoms and $150{ }^{\circ} \mathrm{C}$ for the reaction with $\mathrm{OH}$ radical. The injector was run in the split mode (ratio $1: 10$ ), and the pressure was set to $75.4 \mathrm{kPa}$ for the reaction with $\mathrm{Cl}$ atmos and $82.3 \mathrm{kPa}$ for the reaction with $\mathrm{OH}$ radical. The mobile phase was $\mathrm{He}$ with a flow velocity of $34 \mathrm{~cm} \mathrm{~s}^{-1}$. The injector and detector temperatures were 200 and $300{ }^{\circ} \mathrm{C}$, respectively, for the reaction with $\mathrm{Cl}$ atoms and $300{ }^{\circ} \mathrm{C}$ for both in the reaction with $\mathrm{OH}$ radical.

Theoretical methodology

The reactivity of series of structurally similar organic compounds can be predicted on the basis of PFMO theory (Fleming 2009). Rate constants of organic compound reactions with radicals have been correlated with the energy gap, $\Delta E$, between the highest occupied molecular orbital (HOMO) of the organic molecule and the singly occupied molecular orbital (SOMO) of the electrophilic species. For the reactions of different monoalkenes and dialkenes with $\mathrm{OH}, \mathrm{Cl}, \mathrm{NO}_{3}$ and $\mathrm{O}_{3}$, the following correlations have been reported:

$\operatorname{Ln} k=a /\left(E_{\mathrm{SOMO}}-E_{\mathrm{HOMO}}\right)+b$

where $k$ is the rate constant, $E_{\mathrm{SOMO}}$ and $E_{\mathrm{HOMO}}$ correspond to the energies of the SOMO of the radical and HOMO of the alkene, and $a$ and $b$ are constants reported for each kind of reaction (King et al. 1999 and Timerghazin and Ariya 2001). Nevertheless, if $E_{\text {Somo value can be }}$ considered constant for each radical, the Eq. (4) can be reduced to:

Ln $k=a^{\prime} / E_{\mathrm{HOMO}}+b^{\prime}$

To predict a theoretical value for the rate coefficient of the reactions of cis-3-hexenylformate with different atmospheric radicals through Eq. (5), $E_{\text {HOMO was }}$ calculated for cis-3-hexenylformate at the HF/6-31G** using the Gaussian09 (Rev. C.01) set of programs (Frisch et al. 2009). An initial conformational analysis was carried out for the reagent to obtain the lowest energy conformation. The nature of the stationary points was assessed by means of the normal vibration frequencies calculated from the analytical second derivatives of the energy. 


\section{Results and discussion}

Figure 1 shows plots of the loss of cis-3-hexenylformate versus reference compounds following exposure to $\mathrm{Cl} / \mathrm{OH}$ radicals at room temperature and atmospheric pressure of air or $\mathrm{N}_{2}$. As expected for these relative-rate plots (Eq. 3), straight lines with a zero intercept were obtained, showing in all cases a good linearity. The slopes were calculated using a linear least-square analysis.

For the reaction with $\mathrm{Cl}$ atoms and under our experimental conditions, $\mathrm{OH}$ radical formation is possible via secondary reactions involving $\mathrm{O}_{2}$ (Kaiser and Wallington 1996). To test the potential systematic errors due to $\mathrm{OH}$ reacting with the ester or reference compounds, separate sets of experiments were carried out for all organic pairs using air or $\mathrm{N}_{2}$ as the bath gas. The obtained results, in all cases, were independent of the bath gas used. The good agreement between the results for $\mathrm{Cl}$ with cis-3-hexenylformate in both air and $\mathrm{N}_{2}$ shows that the kinetic rate determinations were independent of the bath gas used and that the possible inference by any other $\mathrm{OH}$ radicals formed when using air as diluent gas was negligible. For such reasons, we report here the averages (with errors $\pm 2 \sigma$ ) of the rate constants for both bath gases and for all the reference compounds used (see Table 1).

Table 1 summarizes the rate coefficients determined in this work for the reactions of $\mathrm{Cl}$ atoms and $\mathrm{OH}$ radical with the unsaturated ester. To obtain the ratio $k_{\text {ester }} / k_{\text {ref }}$, we use a linear regression that takes into account errors in both the abscissa and the ordinate (Brauers and Finlayson-Pitts 1997). Since the accuracy of the ester's rate constant directly depends on the accuracy of the reference rate constant, it is critical to choose an accurate reference rate constant for the determination of kinetic parameters of $\mathrm{cis}$ 3-hexenyl formate reactions. Problems as the $\mathrm{Cl} / \mathrm{OH}$ reaction rate constants are similar in magnitude to the expected rate constants of the studied ester or that the specie possess an un-appropriate retention time are usually found. In the present work, the organic reference compounds used in the study of the reaction with $\mathrm{Cl}$ atoms were cyclohexane, n-octane and propene, whose rate constants for their reactions with $\mathrm{Cl}$ were taken from the values reported by $\mathrm{Li}$ and Pirasteh $(\mathrm{Li}$ and Pirasteh 2006) $(2.91 \pm 0.31) \times 10^{-10} \mathrm{~cm}^{3}$ molecule ${ }^{-1} \mathrm{~s}^{-1}$ and $(3.22 \pm 0.36) \times 10^{-10} \mathrm{~cm}^{3}$ molecule $\mathrm{e}^{-1} \mathrm{~s}^{-1}$ for cyclohexane and octane, respectively; and Stutz et al. (Stutz et al. 1998), $\quad(2.31 \pm 0.29) \times 10^{-10} \mathrm{~cm}^{3}$ molecule $\mathrm{s}^{-1} \mathrm{~s}^{-1}$ for propene. For the $\mathrm{OH}$ reaction, reference compounds were cyclohexane, 1-butene and n-octane, whose rate coefficients were $(6.97 \pm 0.86) \times 10^{-12} \mathrm{~cm}^{3}$ molecule $^{-1} \mathrm{~s}^{-1}$ (Saunders et al. 1994), $(3.10 \pm 0.40) \times 10^{-11} \mathrm{~cm}^{3}$ molecule ${ }^{-1} \mathrm{~s}^{-1}$ (Vakhtin et al. 2003) and $(8.88 \pm 0.31) \times$ $10^{-12} \mathrm{~cm}^{3}$ molecule $\mathrm{s}^{-1} \mathrm{~s}^{-1}$ (Li et al. 2006), respectively. As

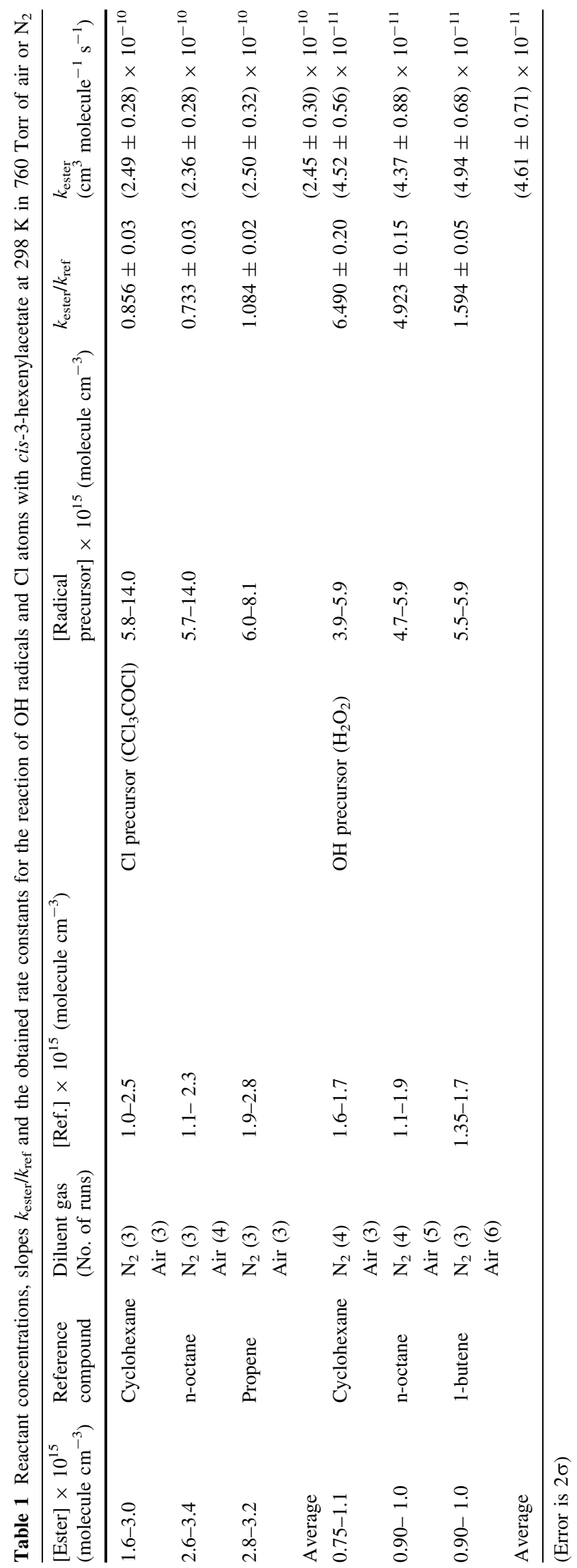



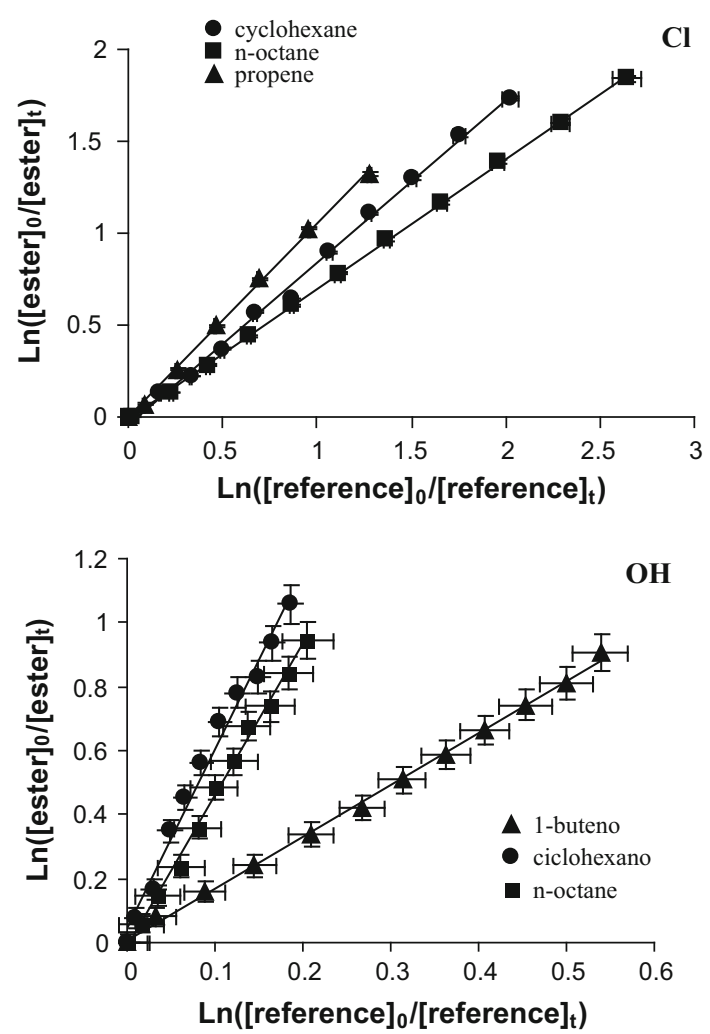

Fig. 1 Relative loss of cis-3-hexenylformate versus reference compounds in the presence of $\mathrm{Cl}$ and $\mathrm{OH}$ radicals at $298 \mathrm{~K}$ and atmospheric total pressure of $\mathrm{N}_{2}$ or Air

can be seen in Table 1, there is good agreement between the rate coefficients obtained using the different reference compounds. Therefore, the rate coefficients for the reaction of $\mathrm{Cl} / \mathrm{OH}$ with the ester are the averages of all determinations i.e., reference organic compounds and bath gas.

The reaction between unsaturated ester and $\mathrm{Cl}$ is very fast $(2.45 \pm 0.30) \times 10^{-10} \mathrm{~cm}^{3}$ molecule $\mathrm{s}^{-1} \mathrm{~s}^{-1}$, approaching the collision-controlled regime; nevertheless, the rate constant for the reaction with $\mathrm{OH}$ radical is lower, $(4.61 \pm 0.71) \times 10^{-11} \mathrm{~cm}^{3}$ molecule ${ }^{-1} \mathrm{~s}^{-1}$. In general, $\mathrm{Cl}$ atoms and $\mathrm{OH}$ radicals have similar mode of attack in their reaction with organic compound, attack by $\mathrm{Cl}$ atoms being faster and somewhat less selective than attack by $\mathrm{OH}$ radicals; however, the subsequent chemistry is similar. Up to our knowledge, no previous kinetic data are available for these reactions, and therefore, no direct comparison with the literature can be made. However, we can compare our rate coefficient values with the available literature data for reactions of other unsaturated esters with $\mathrm{Cl}$ atoms and $\mathrm{OH}$ radicals, see Table 2.
Thus, the reaction of $\mathrm{OH}$ with cis-3-hexenylacetate, unsaturated ester similar to the studied in this work, was previously studied by Atkinson et al. 1995. Rate coefficient of this reaction $(7.84 \pm 1.64) \times 10^{-11} \mathrm{~cm}^{3}$ molecule ${ }^{-1} \mathrm{~s}^{-1}$, even though being lightly high, is in relative good agreement with our value $(4.61 \pm 0.71) \times 10^{-11} \mathrm{~cm}^{3}$ molecule $^{-1} \mathrm{~s}^{-1}$. This small difference, within experimental errors, may be attributed to the use of a unique reference compound (trans-2-butene) in the work of Atkinson et al.

For some unsaturated esters (see Table 2), the rate reaction with $\mathrm{OH}$ radicals is within $(1-5) \times 10^{-11} \mathrm{~cm}^{3}$ molecule ${ }^{-1} \mathrm{~s}^{-1}$. The reactivity increases by the presence of electron-donating substituent, i.e., the positive inductive effect of the alkyl groups $\left(-\mathrm{CH}_{3}\right.$ and $-\mathrm{CH}_{2}$ - groups) in the unsaturated esters increases the charge density on the double-bonded carbon atom, which is indicative of an electrophilic addition mechanism. This can be seen in Table 2 for the reaction of methyl acrylate $\left(\mathrm{CH}_{2}=\mathrm{CHC}(\mathrm{O}) \mathrm{OCH}_{3}\right)$ with $\mathrm{OH}$ radical, $k=(1.3 \pm 0.2) \times 10^{-11} \mathrm{~cm}^{3}$ molecule $\mathrm{s}^{-1} \mathrm{~s}^{-1}$ (Teruel et al. 2006; Blanco et al. 2009a) compared with the value of methyl 3-butenoate $\left(\mathrm{CH}_{2}=\mathrm{CHCH}_{2} \mathrm{C}(\mathrm{O}) \mathrm{OCH}_{3}\right)$ $k=(3.16 \pm 0.57) \times 10^{-11} \mathrm{~cm}^{3}$ molecule ${ }^{-1} \mathrm{~s}^{-1}$ (Colomer et al. 2013), methyl methacrylate $\left(\mathrm{CH}_{2}=\mathrm{C}\left(\mathrm{CH}_{3}\right) \mathrm{C}(\mathrm{O}) \mathrm{OCH}_{3}\right)$, $k=(4.30 \pm 0.98) \times 10^{-11} \mathrm{~cm}^{3}$ molecule ${ }^{-1} \mathrm{~s}^{-1} \quad$ (Blanco et al. 2009a) and methyl 2-butenoate $\mathrm{CH}_{3} \mathrm{CH}=\mathrm{CHC}(\mathrm{O})$ $\left.\mathrm{OCH}_{3}\right), \quad k=(4.65 \pm 0.61) \times 10^{-11} \mathrm{~cm}^{3}$ molecule $\mathrm{s}^{-1}$ (Teruel et al. 2012). As is shown in these examples, this enhancement is higher when the $\mathrm{H}$ atom attached to olefinic is substituted by a $-\mathrm{CH}_{3}$ group than by a $-\mathrm{CH}_{2}$ group. This behavior is observed on both sides of the ester entity: $k_{\mathrm{CH} 3 \mathrm{C}(\mathrm{O}) \mathrm{OCH} 2 \mathrm{CH}=\mathrm{CH} 2}>k_{\mathrm{CH} 3 \mathrm{C}(\mathrm{O}) \mathrm{OCH}=\mathrm{CH} 2}$ (see Table 2$)$. In this way, the cis-3-hexenylformate has a rate constant with $\mathrm{OH}$ radicals higher than the rate constants of the vinyl or allyl acetate, since the ester studied in this work has $-\mathrm{CH}_{2} \mathrm{CH}_{2}$ and $-\mathrm{CH}_{2} \mathrm{CH}_{2} \mathrm{CH}_{3}$ groups on both sides of the double bond, which increase the rate reaction due to the positive inductive effect of these groups.

It is clear from Table 2 that the olefinic units of the esters are more reactive toward $\mathrm{Cl}$ than $\mathrm{OH}$ and that the effect of substituents on the reactivity of the olefinic unit toward $\mathrm{Cl}$ atoms is much less important than that for $\mathrm{OH}$ reactions. The rate constants for the reactions of $\mathrm{Cl}$ atoms with unsaturated esters are close to the gas kinetic limited value from gas collision theory (Blanco et al. 2006; Teruel et al. 2009; Blanco et al. 2008; Blanco et al. 2009b, c; Martín et al. 2010; Teruel et al. 2012; Colomer et al. 2013). Thus, the reaction probability of $\mathrm{Cl}$ atoms with unsaturated esters is high, and the chemical structure consequently plays only a limited role 
Table 2 Comparison of the rate coefficient values for the reaction of $\mathrm{OH}$ radicals and $\mathrm{Cl}$ atoms with a series of esters at $298 \mathrm{~K}$ and atmospheric pressure

\begin{tabular}{|c|c|c|}
\hline Esters & $k_{\mathrm{Cl}} \times 10^{10}\left(\mathrm{~cm}^{3}\right.$ molecule $\left.{ }^{-1} \mathrm{~s}^{-1}\right)$ & $k_{\mathrm{OH}} \times 10^{11}\left(\mathrm{~cm}^{3}\right.$ molecule $\left.{ }^{-1} \mathrm{~s}^{-1}\right)$ \\
\hline $\mathrm{CH}_{2}=\mathrm{CHC}(\mathrm{O}) \mathrm{OCH}_{3}$ & $(2.14 \pm 0.54)^{\mathrm{a}}$ & $(1.30 \pm 0.20)^{\mathrm{b}, \mathrm{c}}$ \\
\hline $\mathrm{CH}_{2}=\mathrm{CHC}(\mathrm{O}) \mathrm{O}\left(\mathrm{CH}_{2}\right)_{3} \mathrm{CH}_{3}$ & $(2.94 \pm 0.23)^{\mathrm{d}}$ & $(1.80 \pm 0.26)^{\mathrm{e}}$ \\
\hline $\mathrm{CH}_{2}=\mathrm{CHCH}_{2} \mathrm{C}(\mathrm{O}) \mathrm{OCH}_{3}$ & $(2.10 \pm 0.35)^{\mathrm{f}}$ & $(3.16 \pm 0.57)^{\mathrm{f}}$ \\
\hline $\mathrm{CH}_{2}=\mathrm{C}\left(\mathrm{CH}_{3}\right) \mathrm{C}(\mathrm{O}) \mathrm{OCH}_{3}$ & $(2.82 \pm 0.93)^{\mathrm{g}}$ & $(4.30 \pm 0.98)^{\mathrm{b}, \mathrm{c}}$ \\
\hline $\mathrm{CH}_{2}=\mathrm{C}\left(\mathrm{CH}_{3}\right) \mathrm{C}(\mathrm{O}) \mathrm{OCH}_{2} \mathrm{CH}_{3}$ & $(2.71 \pm 0.21)^{\mathrm{d}}$ & $(4.58 \pm 0.59)^{\mathrm{h}}$ \\
\hline $\mathrm{CH}_{3} \mathrm{CH}=\mathrm{CHC}(\mathrm{O}) \mathrm{OCH}_{3}$ & $(2.20 \pm 0.55)^{\mathrm{i}}$ & $(4.65 \pm 0.65)^{\mathrm{i}}$ \\
\hline $\mathrm{CH}_{3} \mathrm{C}(\mathrm{O}) \mathrm{OCH}=\mathrm{CH}_{2}$ & $(2.68 \pm 0.91)^{\mathrm{j}}$ & $(2.30 \pm 0.30)^{\mathrm{k}}$ \\
\hline $\mathrm{CH}_{3} \mathrm{C}(\mathrm{O}) \mathrm{OCH}_{2} \mathrm{CH}=\mathrm{CH}_{2}$ & $(1.30 \pm 0.45)^{\mathrm{j}}$ & $(3.06 \pm 0.31)^{1}$ \\
\hline $\mathrm{HC}(\mathrm{O}) \mathrm{OCH}_{2} \mathrm{CH}_{2} \mathrm{CH}=\mathrm{CHCH}_{2} \mathrm{CH}_{3}$ & $(2.45 \pm 0.30)^{\mathrm{m}}$ & $(4.61 \pm 0.71) \mathrm{m}$ \\
\hline $\mathrm{CH}_{3} \mathrm{C}(\mathrm{O}) \mathrm{OCH}_{2} \mathrm{CH}_{2} \mathrm{CH}=\mathrm{CHCH}_{2} \mathrm{CH}_{3}$ & - & $(7.84 \pm 1.64)^{\mathrm{n}}$ \\
\hline
\end{tabular}

${ }^{\mathrm{a}}$ Blanco et al. (2008); ${ }^{\mathrm{b}}$ Teruel et al. (2006); ${ }^{\mathrm{c}}$ Blanco et al. (2009a); ${ }^{\mathrm{d}}$ Martín et al. (2010); ${ }^{\mathrm{e}}$ Blanco and Teruel (2008); ${ }^{\mathrm{f}}$ Colomer et al. (2013); ${ }^{\mathrm{g}}$ Blanco et al. (2009b); ${ }^{\mathrm{h}}$ Blanco et al. (2006); ${ }^{\mathrm{i}}$ Teruel et al. (2012); ${ }^{\mathrm{j}}$ Blanco et al. (2009c); ${ }^{\mathrm{k}}$ Picquet-Varrault et al. (2010); ${ }^{1}$ Picquet-Varrault et al. (2002); ${ }^{\mathrm{m}}$ this work; ${ }^{\mathrm{n}}$ Atkinson et al. (1995)

in determining the magnitude of the rate coefficient in comparison with $\mathrm{OH}$ radicals, whose rate constants with the same unsaturated esters are at least an order of magnitude higher. Therefore, comparing the reactivity of the different esters of the Table 2 toward the $\mathrm{Cl}$ radicals, it can be seen that the reactivity (rate coefficient) is slightly influenced by the increasing substitution at the $\mathrm{C}=\mathrm{C}$ double bond by $-\mathrm{CH}_{2}$ and $-\mathrm{CH}_{3}$ groups .

On the other hand, it is also interesting to compare the reactivity of the cis-3-hexenylformate toward $\mathrm{OH} / \mathrm{Cl}$ radicals with the corresponding alkene. The value obtained in this work for the rate constant of cis-3 hexenylformate with $\mathrm{OH}$ is similar to that found in the literature for the similar structured alkene, cis 3-hexene, $k=6.3 \times 10^{-11} \mathrm{~cm}^{3}$ molecule ${ }^{-1} \mathrm{~s}^{-1}$ (Grosjean and Williams 1992). This indicates that the reaction of $\mathrm{OH}$ with unsaturated esters proceed essentially by $\mathrm{OH}$ addition to the double bond (Le Calvè et al. 2000). Comparison reactivity between the corresponding formate and alkene cannot be made for $\mathrm{Cl}$ radical since the rate coefficient of 3-hexene $+\mathrm{Cl}$ reaction has not been studied yet.

Regarding atmospheric implications of this work can be obtained from a comparison of the lifetimes $(\tau=1 /$ ( $k$ [oxidant]) ) of the cis-3-hexenylformate with respect to gas-phase removal by reaction with the tropospheric oxidant such as $\mathrm{OH}, \mathrm{NO}_{3}, \mathrm{O}_{3}$ and $\mathrm{Cl}$ atoms. Unfortunately, no kinetic data are available for the reaction of this compound with $\mathrm{O}_{3}$ and $\mathrm{NO}_{3}$ radicals, but the corresponding rate coefficients have been estimated by using Eq. (5) and considering the addition to the double bond as the main reaction mechanism.
HOMO energy calculated for cis-3-hexenylformate at the $\mathrm{HF} / 6-31 \mathrm{G}^{* *}$ level was $-9.53 \mathrm{eV}$, and the rate coefficients estimated for the reactions with $\mathrm{OH}, \mathrm{NO}_{3}$, $\mathrm{O}_{3}$ and $\mathrm{Cl}$ are collected in Table 3, (detailed information on the geometry and vibrational frequencies calculated for cis-3-hexenylformate is shown in Supplementary Information). The rate coefficient estimated for the $\mathrm{OH}$ reaction is consistent with the experimental value $(8.0 \%$ of deviation), while the value estimated for $\mathrm{Cl}$ reaction is about twofold of the experimental one. As expected, the reactions with $\mathrm{NO}_{3}$ and $\mathrm{O}_{3}$ must be considerable considerably slower than the corresponding reactions with $\mathrm{OH}$ and $\mathrm{Cl}$.

For the estimation of the tropospheric lifetimes of the formate with respect to reaction with $\mathrm{OH}, \mathrm{NO}_{3}, \mathrm{O}_{3}$ and $\mathrm{Cl}$, the following average oxidant concentrations were considered: $10^{6}$ radical $\mathrm{cm}^{-3}$ for $\mathrm{OH}$ radicals (Bloss et al. 2005), $5 \times 10^{8}$ radical $\mathrm{cm}^{-3}$ for $\mathrm{NO}_{3}$ radical (Atkinson and Arey 2003), $7 \times 10^{11}$ molecule $\mathrm{cm}^{-3}$ for $\mathrm{O}_{3}$ (Logan 1985) and $5 \times 10^{3}$ atom $\mathrm{cm}^{-3}$ for chlorine atoms (Pszenny et al. 1993; Wingenter et al. 1996). Table 3 summarizes the lifetimes estimated from both the experimental and theoretical rate coefficients obtained in this work for the reactions of the formate with $\mathrm{OH}, \mathrm{NO}_{3}, \mathrm{O}_{3}$ and $\mathrm{Cl}$.

It is clear from these data that the reactions with $\mathrm{OH}$ and $\mathrm{NO}_{3}$ radicals should play a major role in the atmospheric destruction of cis-3-hexenylformate. Lifetimes estimated for the reaction with $\mathrm{O}_{3}$ are about three times the corresponding to the reactions with $\mathrm{OH}$ and $\mathrm{NO}_{3}$, and hence, the role of $\mathrm{O}_{3}$ in the oxidation of cis-3- 


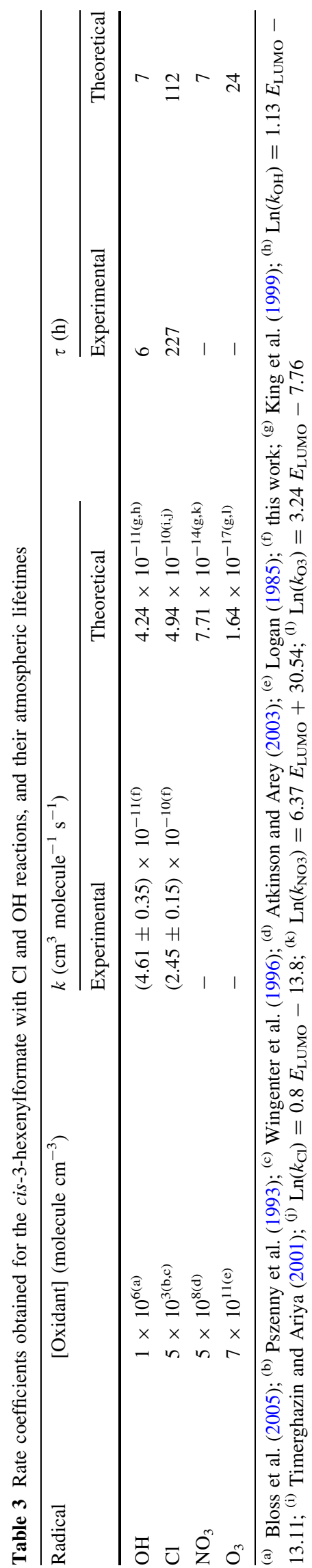

hexenylformate should not be wholly discarded. On a global scale, oxidation initiated by $\mathrm{Cl}$ atoms will not compete with that initiated by more abundant radicals such as $\mathrm{OH}$ and $\mathrm{NO}_{3}$. However, reactions of $\mathrm{Cl}$ atoms are, in general, faster than the corresponding ones with $\mathrm{OH}$ and $\mathrm{NO}_{3}$ radicals, which make these reactions potentially important in areas where the atomic chlorine concentrations are high. In this regard, recent studies suggest that in the early morning, the production rate of the $\mathrm{Cl}$ atoms exceeds the production of $\mathrm{OH}$ from 2 to $3 \mathrm{~h}$ after sunrise due to high concentrations of $\mathrm{ClNO}_{2}$, (Osthoff et al. 2008; Thornton et al. 2010; Mielke et al. 2011; Phillips et al. 2012). In this respect, $\mathrm{Cl}$ concentration of $\sim 10^{6}$ molecule $\mathrm{cm}^{-3}$ was estimated from the concentrations and photolysis rate of $\mathrm{ClNO}_{2}$ in early morning air masses (Osthoff et al. 2008). Under such conditions, the lifetime of cis-3-hexenylformate with respect to this oxidant would be $\sim 1 \mathrm{~h}$, and therefore, the reaction of $\mathrm{Cl}$ atoms with the formate may constitute a competitive channel for its atmospheric removal. Loss by photolysis can be considered negligible since it is photolytically stable in the actinic region of the electromagnetic spectrum (Blanco et al. 2009a). The other possible atmospheric loss processes for esters are dry and wet depositions. Both will be less important since these compounds are highly volatile and sparingly soluble in water. Their Henry's law solubility constant at $298 \mathrm{~K}$ was estimated to be around $10 \mathrm{M} \mathrm{atm}^{-1}$ (Kutsuna et al. 2005).

The relatively short atmospheric lifetimes of the ester due to reaction with the studied radicals indicate that the compound will be oxidized near its emission source where can contribute to the formation of $\mathrm{O}_{3}$ and other photo-oxidants (Blanco et al. 2010). Consequently, this emission will have mainly a local impact concerning the photochemical smog production. Therefore, further studies on the product distributions, rate temperature dependence, need to be performed for a better understanding of its contribution to photo-oxidants and SOA formation in the atmosphere.

\section{Conclusion}

We have used a smog chamber/GC-FID to study rate constants of the reactions of the cis-3-hexenylformate with $\mathrm{OH}$ radicals and $\mathrm{Cl}$ atoms at $298 \mathrm{~K}$ and atmospheric pressure for the first time. cis-3-hexenylformate is expected to have short atmospheric lifetimes due to its high gasphase reactivity with $\mathrm{Cl}$ and $\mathrm{OH}$ radicals and may actively contribute to the smog formation mainly in areas near to its anthropogenic sources. 
According to the reactivity of unsaturated esters observed in other studies, an initial addition step of the $\mathrm{Cl} /$ $\mathrm{OH}$ radical to the double bond of the ester and subsequent reactions of the radicals formed are expected. However, more information is necessary in order to propose detailed mechanisms, so further experiments to study the products of both reactions would be desirable.

Acknowledgments This work was supported by the Spanish Ministerio de Ciencia e Innovación (Project CGL2011-24799) and Junta de Comunidades de Castilla-La Mancha (Project PEII09-0262-2753).

\section{References}

Arey J, Winer AM, Atkinson R, Aschmann SM, Long WD, Morrison CL (1991) The emission of (z)-3-hexen-1-ol, (z)-3hexenylacetate and other oxygenated hydrocarbons from agricultural plant species. Atmos Environ 25A:1063-1075

Arsene C, Bougiatioti A, Kanakidou M, Bonsang B, Mihalopoulos N (2007) Tropospheric $\mathrm{OH}$ and $\mathrm{Cl}$ levels deduced from nonmethane hydrocarbon measurements in a marine site. Atmos Chem Phys 7(17):4661-4673

Atkinson R, Arey J (2003) Atmospheric degradation of volatile organic compounds. Chem Rev 103:4605-4638

Atkinson R, Arey J, Aschmann SM, Corchnoy SB, Shu Y (1995) Rate constant for the gas-phase reactions of cis-3-hexen-1-ol, cis-3hexeylacetate, trans-2-hexenal and linalool with $\mathrm{OH}$ and $\mathrm{NO}_{3}$ radicals and $\mathrm{O}_{3}$ at $296 \pm 2 \mathrm{~K}$, and $\mathrm{OH}$ radical formation yields from the $\mathrm{O}_{3}$ reactions. Int J Chem Kinet 27:941-955

Bicchi C, D'Amato A, David F, Sandra P (1989) Capturing of volatiles emitted by living plants by means of thick film open tubular traps. J High Res Chrom 12:316-321

Blanco MB, Teruel MA (2008) Photodegradation of butyl acrylate in the troposphere by $\mathrm{OH}$ radicals: kinetics and fate of 1,2hydroxyalcoxy radicals. J Phys Org Chem 21:397-401

Blanco MB, Taccone RA, Lane SI, Teruel MA (2006) On the OHinitiated degradation of methacrylates in the troposphere: gasphase kinetics and formation of pyruvates. Chem Phys Lett 429:389-394

Blanco MB, Bejan I, Barnes I, Wiesen P, Teruel MA (2008) Tropospheric chemical degradation of methyl acrylate and butyl methacrylate initiated by chlorine atoms. Geophys Res Abstr 10:EGU2008-A-09060

Blanco MB, Bejan I, Barnes I, Wielsen P, Teruel MA (2009a) OHinitiated degradation of unsaturated esters in the atmosphere: kinetics in the temperature range of 287-313K. J Phys Chem 113:5958-5965

Blanco MB, Bejan I, Barnes I, Wiesen P, Teruel MA (2009b) Temperature-dependent rate coefficients for the reactions of $\mathrm{Cl}$ atoms with methyl methacrylate, methyl acrylate and butyl methacrylate at atmospheric pressure. Atmos Environ 43:5996-6002

Blanco MB, Bejan I, Barnes I, Wielsen P, Teruel MA (2009c) The Clinitiated degradation of $\mathrm{CH}_{2}=\mathrm{CHOC}(\mathrm{O}) \mathrm{CH}_{3}, \mathrm{CH}_{2}=\mathrm{CHCH}_{2} \mathrm{O}$ $\mathrm{C}(\mathrm{O}) \mathrm{CH}_{2} \mathrm{CH}_{3}$ and $\mathrm{CH}_{2}=\mathrm{CHC}(\mathrm{O}) \mathrm{O}\left(\mathrm{CH}_{2}\right)_{3} \mathrm{CH}_{3}$ in the troposphere. Environ Sci Pollut Res 16:641-648
Blanco MB, Bejan I, Barnes I, Wiesen P, Teruel MA (2010) FTIR product distribution study of the $\mathrm{Cl}$ and $\mathrm{OH}$ initiated degradation of methyl acrylate at atmospheric pressure. Environ Sci Technol 44:7031-7036

Bloss W, Evans MJ, Lee JD, Sommariva R, Heard DE, Pilling MJ (2005) The oxidative capacity of the troposphere: coupling of field measurements of $\mathrm{OH}$ and a global chemistry transport model. Faraday Discuss 130:425-436

Brauers T, Finlayson-Pitts B (1997) Analysis of relative rate measurements. Int J Chem Kinet 29:665-672

Colomer JP, Blanco MB, Peñéñory AB, Barnes I, Wiesen P, Teruel MA (2013) FTIR gas-phase kinetic study on the reactions of $\mathrm{OH}$ radicals and $\mathrm{Cl}$ atoms with unsaturated esters: methyl-3,3dimethyl acrylate, (E)-ethyl tiglate and methyl-3-butenoate. Atmos Environ 79:546-552

Donahue NM, Kroll JH, Anderson JG, Demerjian KL (1998) Direct observations of $\mathrm{OH}$ production from the ozonolysis of olefins. Geophys Res Lett 25:59-62

Finlayson-Pitts BJ, Pitts JN (2000) Chemistry of the upper and lower atmosphere: theory, experiments, and applications. Academic Press, San Diego

Fleming I (2009) Molecular orbitals and organic chemical reactions. Wiley, London

Frisch MJ, Trucks GW, Schlegel HB, Scuseria GE, Robb MA, Cheeseman JR, Scalmani G, Barone V, Mennucci B, Petersson GA, Nakatsuji H, Caricato M, Li, X, Hratchian HP, Izmaylov AF, Bloino J, Zheng G, Sonnenberg JL, Hada M, Ehara M, Toyota K, Fukuda R, Hasegawa J, Ishida M, Nakajima T, Honda Y, Kitao O, Nakai H, Vreven T, Montgomery J A Jr, Peralta JE, Ogliaro F, Bearpark M, Heyd JJ, Brothers E, Kudin KN, Staroverov VN, Kobayashi R, Normand J, Raghavachari K, Rendell A, Burant J C, Iyengar SS, Tomasi J, Cossi M, Rega N, Millam NJ, Klene M, Knox JE, Cross JB, Bakken V, Adamo C, Jaramillo J, Gomperts R, Stratmann RE, Yazyev O, Austin A J, Cammi R, Pomelli C, Ochterski JW, Martin RL, Morokuma K, Zakrzewski VG, Voth GA, Salvador P, Dannenberg JJ, Dapprich S, Daniels AD, Farkas Ö, Foresman JB, Ortiz JV, Cioslowski J, Fox DJ (2009) Gaussian 09, Revision C 01. Gaussian Inc. Wallingford, CT

Galán E, González I, Fabbri B (2002) Estimation of fluorine and chlorine emissions from Spanish structural ceramic industries. The case study of the Bailen area, Southern Spain. Atmos Environ 36:5289-5298

George C, Behnke W, Zetzsch C (2010) Radicals in the atmosphere: a changing world! Chem Phys Chem 11:3059-3062

Grosjean E, Grosjean D (1999) The reaction of unsaturated aliphatic oxygenates with ozone. J Atmos Chem 32:205-232

Grosjean D, Williams EL II (1992) Environmental persistence of organic compounds estimated from structure-reactivity and linear free-energy relationships. Unsaturated aliphatics. Atmos Eviron 26A(8):1395-1405

Helmig D, Klinger LF, Guenther A, Vierling L, Geron C, Zimmerman $P$ (1999) Biogenic volatile organic compound emissions (BVOCs). I. Identifications from three continental sites in the US. Chemosphere 38(9):2163-2187

Kaiser EW, Wallington TJ (1996) Kinetics of the reactions of chlorine atoms with $\mathrm{C}_{2} \mathrm{H}_{4}\left(\mathrm{k}_{1}\right)$ and $\mathrm{C}_{2} \mathrm{H}_{2}\left(\mathrm{k}_{2}\right)$ : a determination of $\Delta \mathrm{H}_{\mathrm{f}}, 298$ for $\mathrm{C}_{2} \mathrm{H}_{3}$. J Phys Chem A 100:4111-4119

Kanakidou M, Seinfeld JH, Pandis SN, Barnes I, Dentener FJ, Facchini MC, van Dingenen R, Ervens B, Nenes A, Nielsen CJ, Swietlicki E, Putaud JP, Balkanski Y, Fuzzi S, Horth J, Moortgat 
GK, Winterhalter R, Myhre CEL, Tsigaridis K, Vignati E, Stephanou EG, Wilson J (2005) Organic aerosol and global climate modelling: a review. Atmos Chem Phys 5:1053-1123

King MD, Canosa-Mas CE, Wayne RP (1999) Frontier molecular orbital correlations for predicting rate constants between alkenes and the tropospheric oxidants $\mathrm{NO}_{3}, \mathrm{OH}$ and $\mathrm{O}_{3}$. Phys Chem Chem Phys 1:2231-2238

Kirstine W, Galbally IE, Ye Y, Hooper MA (1998) Emissions of volatile organic compounds (primarily oxygenated species) from pasture. J Geophys Res 103:10605-10620

König G, Brunda M, Puxbaum H, Hewitt CN, Duckham SC, Rudolph J (1995) Relative contribution of oxygenated hydrocarbons to the total biogenic VOC emissions of selected midEuropean agricultural and natural plant species. Atmos Environ 29:861-874

Kutsuna S, Chen L, Abe T, Mizukado J, Uchimaru T, Tokuhashi K, Sekiya A (2005) Henry's law constants of 2,2,2-trifluoroethyl formate, ethyl trifluoroacetate, and non-fluorinated analogous esters. Atmos Environ 39:5884-5892

Le Calvé S, Mellouki A, Le Bras G, Treacy J, Wenger J, Sidebottom $\mathrm{H}$ (2000) Kinetic studies of $\mathrm{OH}$ and $\mathrm{O}_{3}$ reactions with allyl and isopropenyl acetate. J Atmos Chem 37:161-172

Li Z, Pirasteh A (2006) Kinetic study of the reactions of atomic chlorine with several volatile organic compounds at $240-340 \mathrm{~K}$. Int J Chem Kinet 38:386-398

Li Z, Singh S, Woodward W, Dang L (2006) Kinetics study of $\mathrm{OH}$ radical reactions with n-octane, n-nonane, and n-decane at 240-340K using the relative rate/discharge flow/mass spectrometry technique. J Phys Chem A 110:12150-12157

Logan JA (1985) Tropospheric ozone: seasonal behavior, trends, and anthropogenic influence. J Geophys Res: Atmos 90:1046310482

Martin MP, Gallego-Iniesta MP, Espinosa JL, Tapia A, Cabañas B, Salgado MS (2010) Gas phase reactions of unsaturated esters with $\mathrm{Cl}$ atoms. Environ Sci Pollut Res 17:539-546

Mellouki A, Le Bras G, Sidebottom H (2003) Kinetics and mechanisms of the oxidation of oxygenated organic compounds in the gas phase. Chem Rev 103:5077-5096

Mielke LH, Furgeson A, Osthoff HD (2011) Observation of $\mathrm{ClNO}_{2}$ in a mid-continental urban environment. Environ Sci Technol 45(20):8889-8896

Osthoff HD, Roberts JM, Ravishankara AR, Williams EJ, Lerner BM, Sommariva R, Bates TS, Coffman D, Quinn PK, Dibb JE, Stark H, Burkholder JB, Talukdar RK, Meagher J, Fehsenfeld FC, Brown S (2008) High levels of nitryl chloride in the polluted subtropical marine boundary layer. Nat Geosci 1:324-328

Paulson SE, Orlando J (1996) The reactions of ozone with alkenes: an important source of HOx in the boundary layer. Geophys Res Lett 23(3727-3730): 1

Paulson SE, Chung M, Hasson AS (1999) OH radical formation from the gas-phase reaction of ozone with terminal alkenes and the relationship between structure and mechanism. J Phys Chem A 103:8125-8138

Phillips GJ, Tang MJ, Thieser J, Brickwedde B, Schuster G, Bohn B, Lelieveld J, Crowley JN (2012) Significant concentrations of nitryl chloride observed in rural continental Europe associated with the influence of sea salt chloride and anthropogenic emissions. Geophys Res Lett 39:L10811

Picquet-Varrault B, Doussin JF, Durand-Jolibois SR, Pirali O, Carlier $P$ (2002) Kinetic and mechanistic study of the atmospheric oxidation by $\mathrm{OH}$ radicals of allyl acetate. Environ Sci Technol 36:4081-4086

Picquet-Varrault B, Scarfogliero M, Doussin JF (2010) Atmospheric reactivity of vinyl acetate: kinetic and Mechanistic study of its gas-phase oxidation by $\mathrm{OH}, \mathrm{O}_{3}$, and $\mathrm{NO}_{3}$. Environ Sci Technol 44:4615-4621

Pimentel AS, Tyndall GS, Orlando JJ, Hurley MD, Wallington TJ, Sulbaek Andersen MP, Marshall P, Dibble TS (2010) Atmospheric chemistry of isopropyl formate and tert-butyl formate. Int J Chem Kinet 42:479-498

Pszenny AAP, Keene WC, Jacob DJ, Fan S, Maben JR, Zetwo MP, Springer-Young M, Galloway JN (1993) Evidence of inorganic chlorine gases other than hydrogen chloride in marine surface air. Geophys Res Lett 20:699-702

Rodríguez A, Rodríguez D, Soto A, Bravo I, Diaz-de-Mera Y, Notario A, Aranda A (2012a) Products and mechanism of the reaction of $\mathrm{Cl}$ atoms with unsaturated alcohols. Atmos Environ 50:214-224

Rodríguez D, Rodríguez A, Garzon A, Granadino-Roldan JM, Soto A, Aranda A, Notario A (2012b) Kinetic and mechanistic study of the atmospheric reaction of $\mathrm{MBO} 331$ with $\mathrm{Cl}$ atoms. Mol Phys 110:2941-2950

Saunders SM, Baulch DL, Cooke KM, Pilling MJ, Smurthwaite PI (1994) Kinetics and mechanisms of the reactions of $\mathrm{OH}$ with some oxygenated compounds of importance in tropospheric chemistry. Int J Chem Kinet 26:113-130

Stutz J, Ezell MJ, Ezell AA, Finlayson-Pitts BJ (1998) Rate constants and kinetic isotope effects in the reactions of atomic chlorine with n-butane and simple alkenes at room temperature. J Phys Chem A 102:8510-8519

Teruel MA, Lane S, Mellouki A, Solignac G, Le Bras G (2006) OH reaction rate constants and UV absorption cross-sections of unsaturated esters. Atmos Environ 40:3764-3772

Teruel MA, Achad M, Blanco MB (2009) Kinetic study of the reactions of $\mathrm{Cl}$ atoms with $\alpha, \beta$-unsaturated carbonyl compounds at atmospheric pressure and structure relations (SARs). Chem Phys Lett 479:25-29

Teruel MA, Benitez-Villalta J, Caballero N, Blanco B (2012) Gasphase oxidation of methyl crotonate and ethyl crotonate. Kinetic study of their reactions toward $\mathrm{OH}$ radicals and $\mathrm{Cl}$ atoms. J Phys Chem A 116:6127-6133

Thornton JA, Kercher JP, Riedel TP, Wagner NL, Cozic J, Holloway JS, Dube WP, Wolfe GM, Quinn PK, Middlebrook AM, Alexander B, Brown SS (2010) A large atomic chlorine source inferred from mid-continental reactive nitrogen chemistry. Nature 464:271-274

Timerghazin QK, Ariya PA (2001) Kinetics of the gas-phase reaction of atomic chlorine with selected monoterpenes. Phys Chem Chem Phys 3:3981-3986

Vakhtin AB, Murphy JE, Leone SR (2003) Low-temperature kinetics of reactions of $\mathrm{OH}$ radical with ethene, propene and 1-butene. J Phys Chem A 107:10055-10062 
Winer AM, Arey J, Atkinson R, Aschmann SM, Long WD, Morrison L, Olszyk DM (1992) Emission rates of organics from vegetation in Californias's central valley. Atmos Environ 26A:2647-2659

Wingenter OW, Kubo MK, Blake NJ, Smith TW, Blake DR, Rowland

FS (1996) Hydrocarbon and halocarbon measurements as photochemical and dynamical indicators of atmospheric hydroxyl, atomic chlorine, and vertical mixing obtained during Lagrangian flights. J Geophys Res 101:4331-4340 